\title{
Kajian Sarana Prasarana Pendukung Kesiapsiagaan Sekolah Terhadap Bencana Gempabumi Di Smp Muhammadiyah 3 Cawas
}

\author{
Firda Nur Fatta ${ }^{1, *}$, Tika Melinda ${ }^{1}$, Rose Ana Anggun Fajariyah ${ }^{1}$, Dhandy Armikko \\ Putro $^{1,}$ Rawi Akbar Pratama ${ }^{1,}$ Zaid Ali Wardana ${ }^{1}$
}

Program Studi Pendidikan Geografi, Fakultas Keguruan dan Ilmu Pendidikan

Universitas Muhammadiyah Surakarta, Jawa Tengah 57162

Email : firdanf88@gmail.com, tikamelinda06@gmail.com, roseanaanggunf@gmail.com, dandekartro007@gmail.com, akbarp666@gmail.com, zaidaliwardana@gmail.com

Dikirim : 14 Januari 2020

Diterima: 31 Maret 2020

\begin{abstract}
Abstrak: Dalam rangka mengurangi dampak dari bencana gempabumi dalam sebuah komunitas diperlukan adanya mitigasi yang baik. Mitigasi tersebut dapat berupa mitigasi struktural dan non struktural. Mitigasi bencana gempa bumi dapat dilakukan melalui upaya pembangunan sarana fisik yang memadai. Hal ini, setidaknya dapat meminimalkan resiko bilamana terjadi bencana gempabumi di sekolah, menginggat gempabumi terjadi sewaktu - waktu dan sebagian besar waktu siswa dihabiskan di sekolah. Adanya sarana fisik yang memadai tentu menurunkan resiko serta dapat meningkatkan kesiapsiagaan dalam menghadapi bencana gempa bumi. Tujuan dari penelitian ini adalah untuk Mengetahui tingkat kesiapsiagaan SMP Muhammadiyah 3 Cawas terhadap bencana gempa bumi ditinjau dari aspek sarana prasarana pendukung kesiapsiagaan bencana gempa bumi. Metode penelitian ini menggunakan metode deskriptif kuantitatif, adapun populasi dalam penelitian ini yaitu guru dan siswa SMP Muhammadiyah 3 Cawas, Kabupaten Klaten dengan teknik nonprobability sampling. Hasil penelitian menunjukan sarana prasarana pendukung kesiapsiagaan sekolah terhadap bencana gempabumi masih kurang siap jika dilihat dari rerata parameter struktural sekolah.
\end{abstract}

Kata kunci: Mitigasi Struktural, Kesiapsiagaan, Gempabumi, Google Skechup

\begin{abstract}
In order to reduce the impact of an earthquake in a community, good mitigation is needed. There are two types mitigation, structural and non-structural. Earthquake mitigation can be form of physical structural development. This can occur when an earthquake happen at school, remembering that an earthquake occurred during the time and most of the students spent their time at school. The good physical facilities can certainly increase preparedness to face an earthquake. The purpose of this study was to determine the level of preparedness of Cawas Muhammadiyah 3 Junior High School on earthquake disasters in terms of infrastructure facilities to supporting earthquake disaster preparedness. This research method uses quantitative descriptive method, while the population in this study are teachers and students of SMP Muhammadiyah 3 Cawas, Klaten Regency with nonprobability sampling techniques. The results showed that the infrastructure supporting school preparedness for earthquakes was not ready enaugh, viewed from the average structural parameters of the school.
\end{abstract}

Keywords: Structural Mitigation, Preparedness, Earthquakes, Google Skechup 


\section{Pendahuluan}

Indonesia tersusun dalam tiga zona geologi atau berada pada pertemuan tiga lempeng lithosfer. Lempeng Samudra Pasifik yang bergerak ke arah barat-barat laut dengan kecepatan sekitar $10 \mathrm{~cm}$ per tahun, Lempeng Samudra India-Benua Australia (Indo-Australia) yang bergerak ke arah utara-timur laut dengan kecepatan sekitar $7 \mathrm{~cm}$ per tahun, serta Lempeng Benua Eurasia yang relative diam. namun hasil perubahan posisi menunjukkan gerakan lempeng Eurasia ke arah barat daya dengan kecepatan mencapai $13 \mathrm{~cm}$ per tahun (Kementerian ESDM, 2009).

Keadaan geologis Indonesia inilah yang kemudian menimbulkan tingginya angka kejadian gempa bumi di Indonesia. Pada pertengahan Tahun 2019, Badan Meteorologi Klimatologi dan Geofisika (BMKG) mencatat peristiwa gempa bumi di Indonesia mencapai angka 841 kejadian gempa bumi. Hal ini menunjukan bahwa negara Indonesia merupakan negara dengan kerawanan bencana gempa bumi tinggi. Mengingat banyaknya peristiwa gempa bumi yang terjadi, maka perlu adanya kesadaran penuh dari masyarakat mengenai mitigasi bencana khususnya mitigasi bencana gempa bumi.

Mitigasi merupakan suatu upaya yang ditujukan untuk mengurangi dampak dari bencana baik bencana alam, bencana non alam maupun gabungan dari keduanya dalam sebuah komunitas masyarakat (UU No.24 Tahun 2007). Mitigasi bencana gempa bumi dapat dilakukan melalui upaya pembangunan sarana fisik yang memadai. Hal ini, setidaknya dapat meminimalkan resiko bilamana terjadi bencana gempa bumi. Adanya sarana fisik yang memadai tentu akan menurunkan resiko serta dalam saat bersamaan meningkatkan kesiapsiagaan dalam menghadapi bencana gempa bumi.

Menurut Carter (1991), kesiapsiagaan adalah upaya yang dilaksanakan untuk mengantisipasi kemungkinan terjadinya bencana guna menghindari jatuhnya korban jiwa, kerugian harta benda, dan berubahnya tata kehidupan masyarakat. Ditilik dari hal ini, kesiapsiagaan tentu menjadi komponem penting dalam upaya mengurangi dampak peristiwa terjadinya bencana alam khususnya gempa bumi. Cara terbaik menghadapi terjadinya gempa bumi adalah dengan mengurangi resiko yang mungkin terjadi.

Upaya pengurangan resiko bencana gempa bumi perlu dilakukan di lingkup sekolah. Salah satu alasannya adalah gempa bumi merupakan bencana yang tidak bisa diprediksi waktu kedatangannya. Fenomena ini hendaknya menjadi concern bersama bagi para pemangku kepentingan karena sebagian besar waktu siswa dihabiskan di sekolah. Perlu adanya pengawasan dan monitoring fasilitas serta sarana dan prasarana untuk mempersiapkan kemungkinan terjadinya gempa, sehingga dapat menekan jumlah korban akibat gempa bumi terutama pada saat aktivitas belajar - mengajar di lingkungan sekolah.

Pengurangan resiko bencana gempa bumi di sekolah menjadi penting mengingat dari peristiwa bencana gempa bumi sebelumnya, banyak korban datang dari komunitas sekolah. Pada Tahun 2018 Badan Nasional Penanggulangan Bencana (BNPB) mencatat bencana gempa dan tsunami Sulawesi Tengah mengakibatkan sebanyak 23 orang siswa meninggal dunia, 35 orang siswa hilang, dan 1 orang mengalami luka berat. Sementara untuk pengajar dan tenaga kependidikan, 22 orang tercatat meninggal dunia, 14 orang hilang, 2 orang harus dirawat inap, dan 41 orang mengungsi. Banyaknya komponen komunitas sekolah menjadi korban lantaran kejadian gempa dan tsunami terjadi pada saat aktivitas belajar - mengajar di sekolah.

Dampak gempa bumi dan tsunami yang terjadi dalam lingkup sekolah adalah kerusakan sarana dan prasarana bangunan. Kerusakan bangunan sekolah mengakibatkan terganggunya proses pembelajaran siswa di sekolah. Data Kemendikbud menunjukkan lebih dari 7.000 sekolah rusak berat akibat gempa dan tsunami sejak Tahun 2004.

Kerusakan sarana prasarana sekolah akibat bencana gempa bumi, menjadikan upaya peminimalisiran dampak bencana gempa bumi di sekolah menjadi penting. Termasuk didalamnya kajian mengenai identifikasi pembangunan serta ketersediaan sarana fisik yang menjadi upaya pendukung kesiapsiagaan bencana gempa bumi dalam lingkungan sekolah. Kajian sarana prasarana dapat dilakukan pada lingkup 
sekolah sebagai upaya kesiapsiagaan di lingkungan sekolah, selain itu juga dapat menjadi upaya utuk menyampaikan pentingnya mitigasi bencana sejak dini.

Maka dari itu dengan tujuan untuk melakukan kajian mengenai sarana prasarana sebagai upaya pendukung kesiapsiagaan bencana di SMP M 3 Cawas, penulis menyusun penelitian dengan tema besarnya adalah sarana - prasarana pendukung kesiapsiagaan bencana gempa bumi. Penulis menentukan judul penelitian sebagai berikut, Kajian Sarana Prasarana Pendukung Kesiapsiagaan Sekolah terhadap Bencana Gempa Bumi di SMP Muhammadiyah 3 Cawas. (Studi Kasus di Kecamatan Cawas, Kabupaten Klaten).

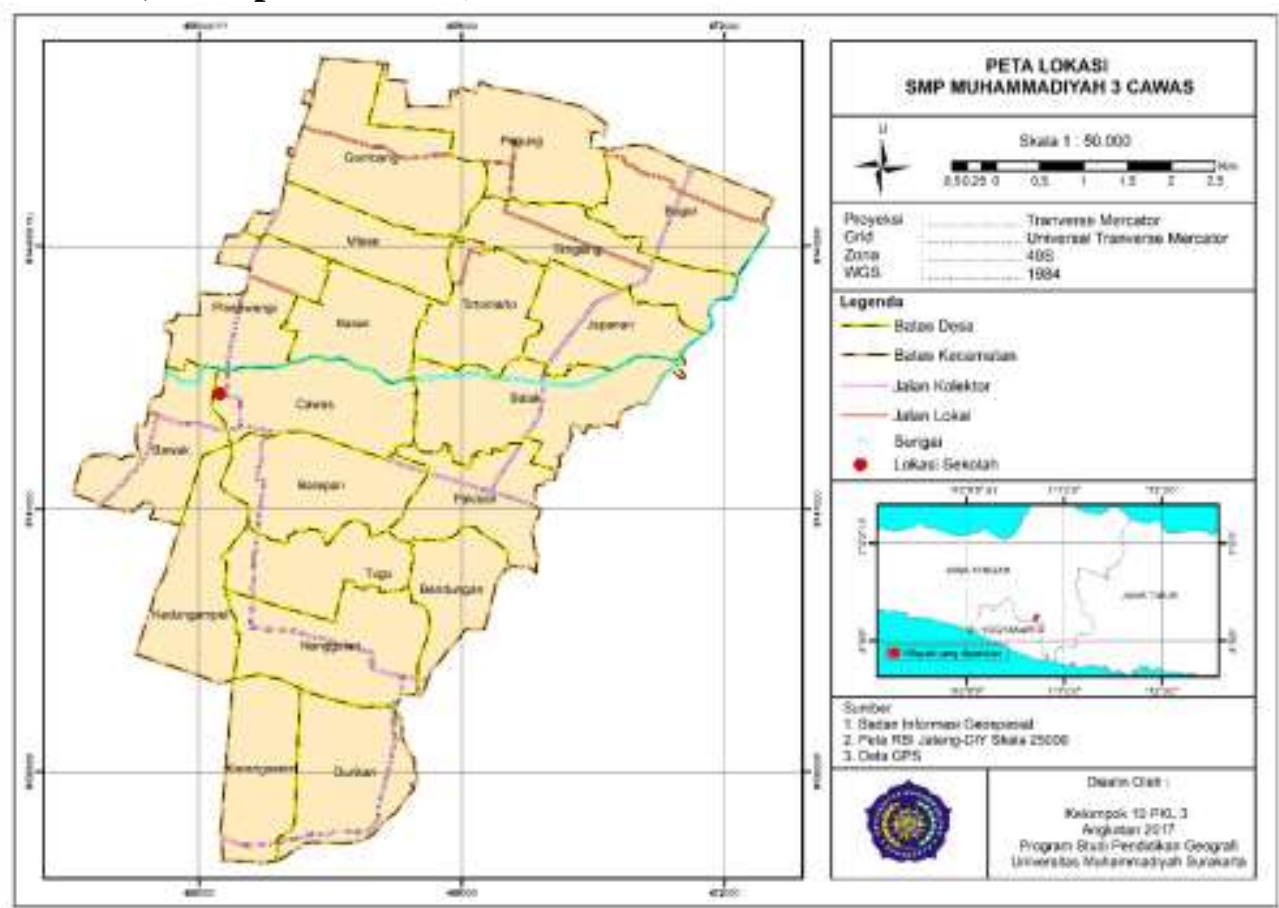

Gambar 1. Peta Lokasi Penelitian (Olah Data Peneliti, 2019)

\section{Metode Penelitian}

Penelitian ini adalah penelitian deskriptif kuantitatif. Metode yang digunakan dalam penelitian ini adalah metode kuantitatif. Metode kuantitatif adalah metode penelitian yang berlandaskan pada filsafat positivisme, digunakan untuk meneliti pada populasi atau sampel tertentu, pengumpulan data menggunakan instrumen penelitian, analisis data bersifat kuantitatif atau statistik, dengan tujuan untuk menguji hipotesis yang telah ditetapkan (Sugiyono, 2017). Sumber utama yang menjadi data penelitian berada di lokasi SMP M 3 Cawas. Penelitian ini adalah siswa dan guru SMP M 3 Cawas. Waktu pelaksanaan penelitian ini dilaksanakan mulai bulan September hingga bulan Desember.

\section{Pengumpulan data}

\section{Populasi}

Populasi adalah wilayah generalisasi yang terdiri atas obyek atau subyek yang mempunyai kuantitas dan karakteristik tertentu yang ditetapkan oleh peneliti untuk dipelajari dan kemudian ditarik kesimpulannya (Sugiyono, 2015). Adapun populasi dalam penelitian ini yaitu guru dan siswa SMP Muhammadiyah 3 Cawas, Kabupaten Klaten. Teknik penentuan jumlah populasi menggunakan data komunitas sekolah.

\section{Teknik Sampling}


Teknik yang digunakan oleh peneliti dalam mengambil sampel yaitu teknik nonprobability sampling yaitu teknik penentuan sampel bila semua anggota populasi dijadikan sampel. Pada saat di lapangan peneliti melakukan observasi, wawancara, dan dokumentasi. Setelah semua data terkumpul maka data tersebut akan diolah dengan menggunakan statistik.

\section{Tempat Penelitian}

Tempat yang dijadikan sebagai objek penelitian adalah SMP M 3 Cawas.

\section{Pelaku dan Narasumber}

Pelaku dan narasumber dari penelitian ini adalah guru dan siswa SMP Muhammadiyah 3 Cawas, Kabupaten Klaten.

\section{Aktivitas}

Aktivitas pengumpulan data dilakukan dengan observasi, pembagian kuesioner, wawancara serta dokumentasi di SMP M uhammadiyah 3 Cawas.

\section{Analisis data}

Teknik analisa data merupakan suatu langkah yang paling menentukan dari suatu penelitian, karena analisa data berfungsi untuk menyimpulkan hasil penelitian. Adapun langkah-langkah yang dilakukan dalam menggunakan teknik analisis ini adalah sebagai berikut:

1. Koding

Koding merupakan usaha memberikan identitas atau pengelompokkan pengklasifikasikan data dari respon-respon hasil penelitian ke dalam kelas-kelas tertentu. Setiap jenis data masuk dalam suatu kelas tertentu, diberi nomor kode. Setiap data hanya masuk dalam satu kelas dan satu kode. Hal ini akan memudahkan data untuk diproses lebih lanjut terutama bila menggunakan komputer. Keuntungan lain dari pemberian kode ini adalah menghemat memori komputer dan mempercepat proses analisis. Koding data terhadap jawaban tertutup lebih mudah dibanding pengkodean pada jawaban terbuka. Pengkodean dapat dilakukan dengan cara memberi nomor kode pada sejumlah option/pilihan jawaban yang telah ditentukan pada setiap butir pertanyaan. Pengkodean akan lebih mudah lagi apabila sejak awal ketika menyusun kuesioner setiap butir pertanyaan dan jawaban yang tersedia telah diberi nomor kode. Kegiatan untuk merancang pengkodean pada saat penyusunan kuesioner ini dikenal dengan istilah precoding.

2. Tabulasi

Tabel frekuensi merupakan dasar untuk melakukan pengolahan data lebih lanjut misalnya tabulasi silang, korelasi bahkan regresi. Melalui tabulasi silang dapat digunakan untuk:

a. Mengetahui apakah jawaban responden atas satu pertanyaan dengan pertanyaan lainnya yang saling berkaitan konsisten.

b. Melakukan analisis satu variabel.

c. Mengetahui distribusi data antarkategori.

d. Menentukan variabel yang dapat ditindaklanjuti dengan tabulasi silang.

Tabulasi frekuensi biasanya dilanjutkan dengan pengolahan persentase untuk tiap kategori. Melalui persentase juga dapat diperoleh perbandingan relatif antar kategori.

3. Grafik

Pengunaan grafik dalam penyajian data ialah untuk menunjukkan perbandingan antara data satu dengan data yang lain secara informasif yang kualitatif dengan tampilan yang sederhana. Data-data yang berupa uraian deskriptif yang banyak dan juga kompleks bisa diubah menjadi bentuk yang sederhana dengan menggunakan grafik.

\section{Hasil Penelitian dan Pembahasan}

\begin{tabular}{|l|l|l|}
\hline No & \multicolumn{1}{|c|}{ Komponen Nilai } \\
\hline 1 & Fondasi & 100 \\
\hline 2 & Balok Bangunan & 40 \\
\hline
\end{tabular}




\begin{tabular}{|l|l|l|}
\hline 3 & Dinding & 0 \\
\hline 4 & Atap & 35 \\
\hline 5 & Partisi & 50 \\
\hline 6 & Langit-langit & 50 \\
\hline 7 & Pintu dan Jendela & 0 \\
\hline 8 & Ornamen Bangunan & 40 \\
\hline 9 & Tangga Sekolah & 0 \\
\hline 10 & Peralatan & 40 \\
\hline 11 & Perabotan & 34 \\
\hline 12 & Gambar dan Papan & 16,25 \\
\hline 13 & Bahan Berbahaya dan Beracun & 0 \\
\hline 14 & Utilitas yang lain & 0 \\
\hline 15 & Peralatan Pipa Listrik & 80 \\
\hline 16 & Lingkungan Sekitar Sekolah & 100 \\
\hline & Jumlah & 585,25 \\
\hline & Rata-rata & 36,57 \\
\hline
\end{tabular}

Tabel 1. (Olah Data Peneliti, 2019)

\section{Struktural}

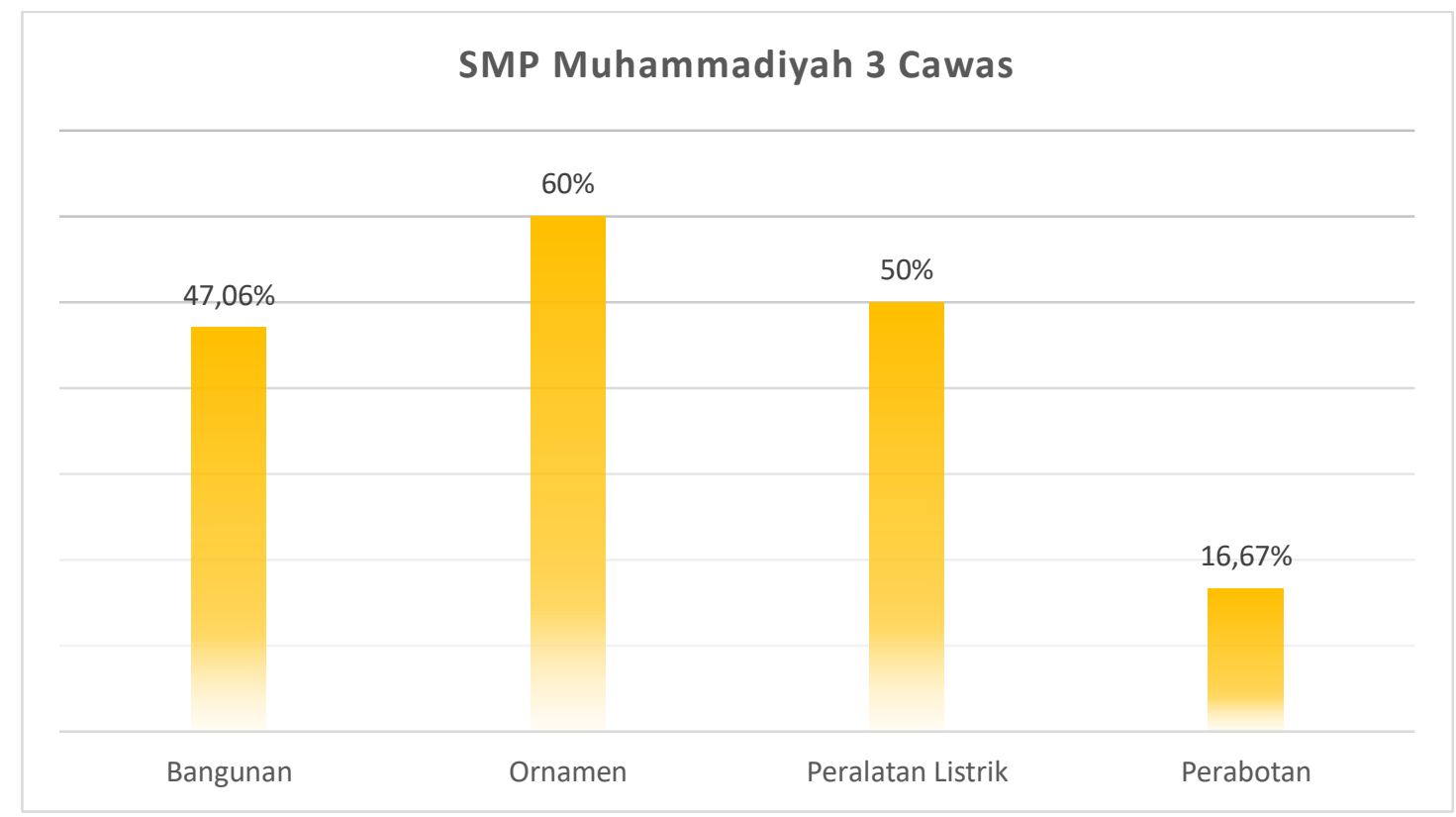

Gambar 2. Struktural (Olah Data Peneliti, 2019)

Pada gambar 2 menunjukan tingkat kesiapan struktural sekolah dalam menghadapi bencana gempabumi. Berdasarkan grafik diatas sarana prasarana pendukung kesiapsiagaan sekolah terhadap bencana gempa bumi di SMP Muhammadiyah 3 Cawas ditinjau dari parameter sruktural sekolah. Parameter tersebut meliputi bangunan, ornament, peralatan listrik, serta prabotan.

Parameter bangunan meliputi fondasi, balok, dinding, atap, langit - langit, pintu dan jendela, lantai, tangga serta lantai dan keramik. Hasil pengolahan data menunjukan parameter bangunan mencapai nilai indeks 47,06 \% atau dapat dikatakan bahwa nilai ini masuk kedalam kategori kurang siap, sehingga dapat dikatakan tingkat kesiapan bangunan SMP Muhammadiyah 3 Cawas dalam menghadapi bencana gempabumi masih kurang atau rendah.

Pada parameter ornamen yaitu meliputi ornamen tetap seperti lampu, tiang bendera, serta genteng mencapai nilai indeks $60 \%$ atau dapat dikatakan bahwa nilai ini masuk kedalam kategori hampir siap, 
hal ini menunjukkan bahwa kesiapan ornamen yang ada di SMP Muhammadiyah 3 Cawas dalam menghadapi bencana gempa bumi yaitu hampir siap.

Parameter selanjutnya yaitu peralatan listrik, hasil nilai indeks pada parameter peralatan listrik yaitu sebesar 50\%, nilai indeks tersebut menunjukan bahwa kesiapan peralatan listrik yang dimiliki SMP Muhammadiyah 3 Cawas masih dalam kategori hampir siap.

Parameter yang terakhir yaitu parameter tentang perabotan, meliputi rak buku, filing cabinet, rak P3K, barang pecah belah serta meja memiliki nilai indeks terendah yaitu dengan nilai $16,67 \%$, niali tersebut masuk dalam kategori belum siap, hal ini menunjukan bahwa kesiapan perabotan yang ada di SMP Muhammadiyah 3 Cawas dalam menghadapi bencana gempa bumi dapat dikatakan masih belum siap atau sangat kurang.

Rata-rata grafik : semua grafik persenannya ditambah terus dibagi banyak grafik : 173.73/4 = $43.4325(\mathbf{4 3 , 4 3 )}$ belum siap

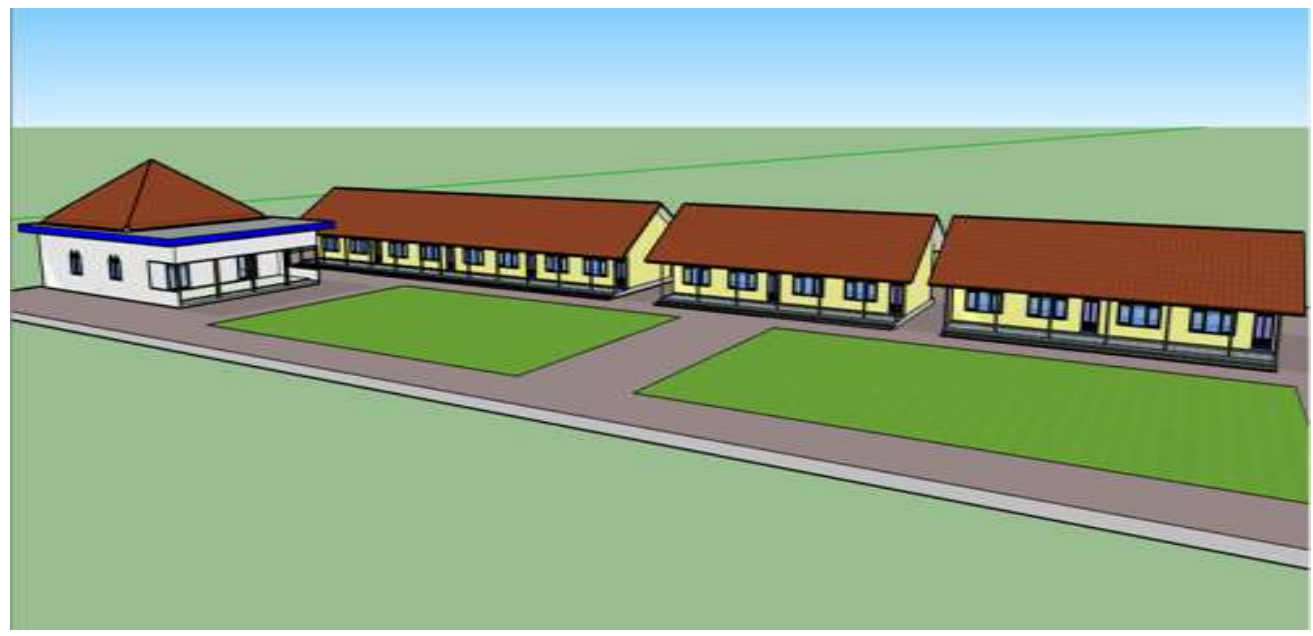

Gambar 3. Kondisi SMP M 3 Cawas (Olah Data Peneliti, 2019)

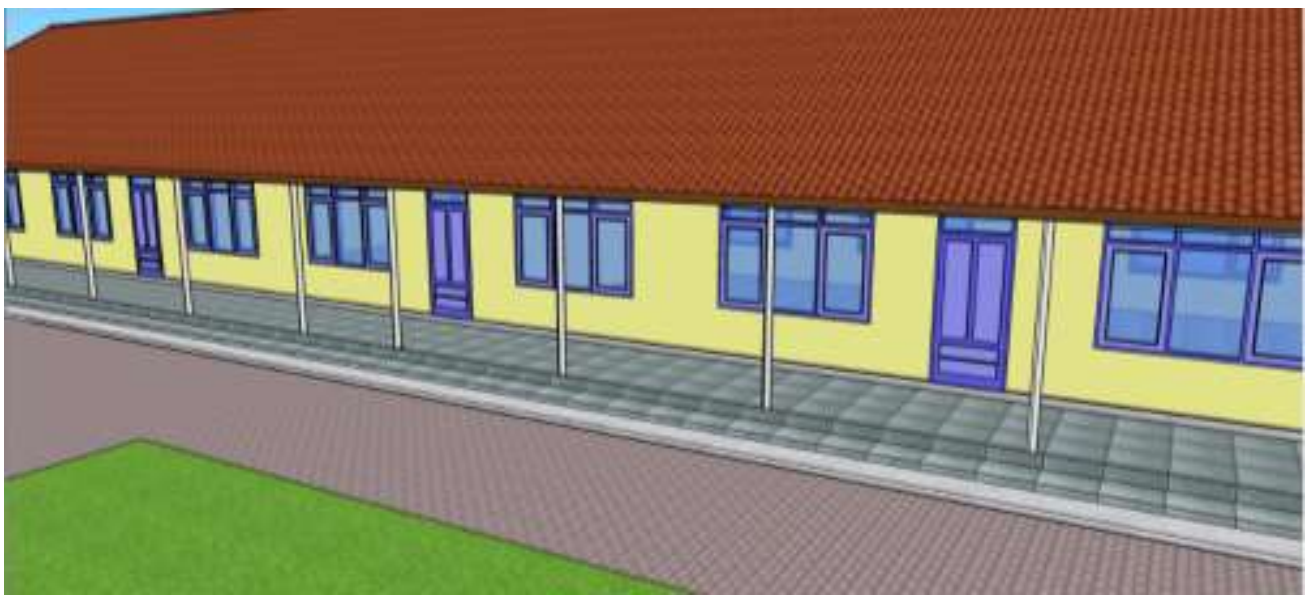

Gambar 4. Kondisi SMP M 3 Cawas (Olah Data Peneliti, 2019)

Kategori atau hasil rekapitulasi kelayakan struktur bangunan SMP Muhammadiyah 3 Cawas dapat dikatakan masih belum siap. Oleh karena itu, SMP Muhammadiyah 3 Cawas memerlukan perhatian khusus dalam hal mitigasi struktural untuk menghadapi bencana gempa bumi, dikarenakan letak SMP Muhammadiyah 3 Cawas merupakan daerah terdampak bencana gempa bumi 2006 dan SMP Muhammadiyah 3 Cawas juga menjadi salah satu sekolah yang lumayan terkena dampaknya. 


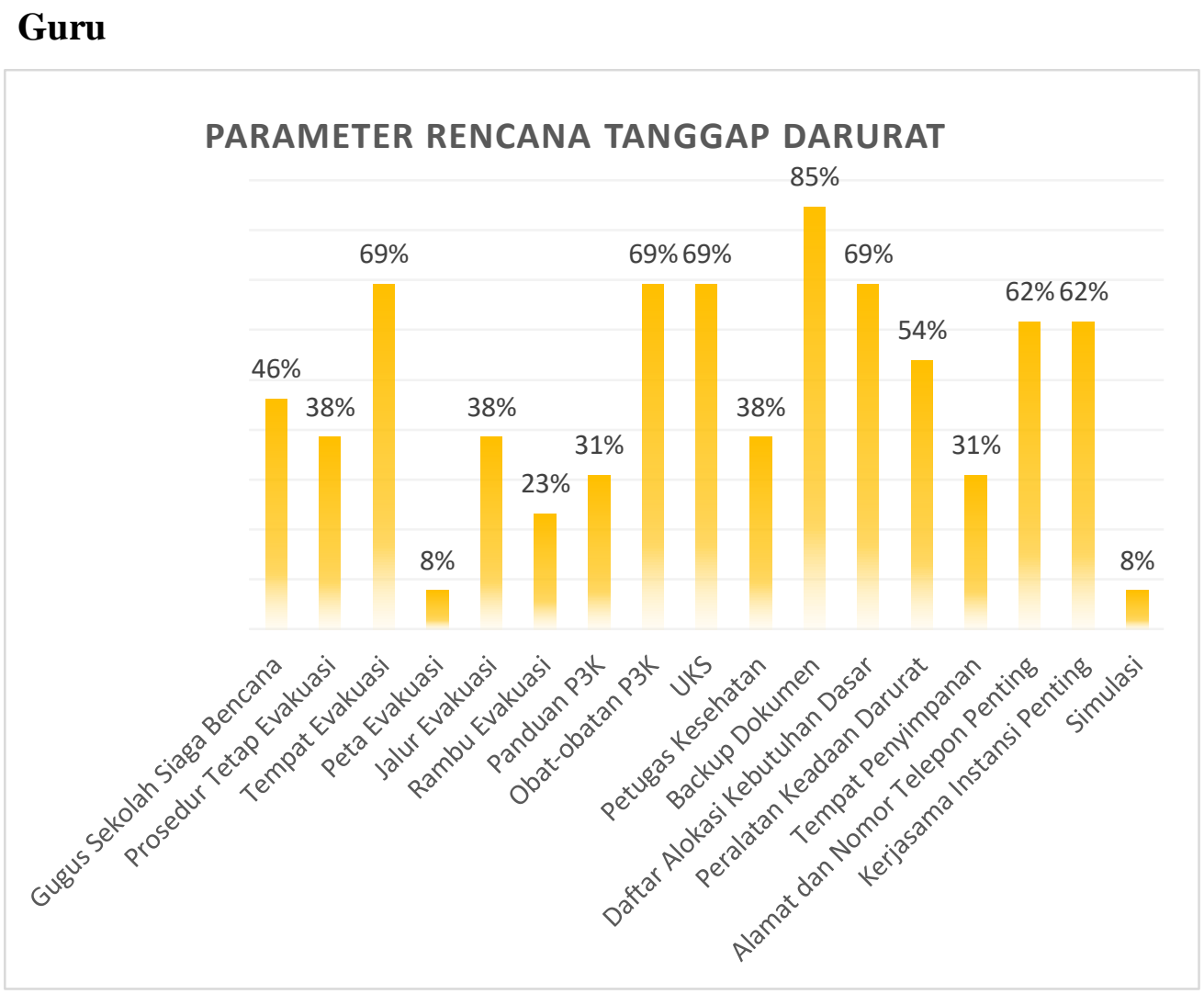

Gambar 5. Parameter Rencana Tanggap Darurat (Olah Data Peneliti, 2019)

Gambar 5 menunjukkan rencana tanggap darurat terhadap sarana prasarana pendukung bencana gempa bumi di SMP Muhammadiyah 3 Cawas. Dari data diatas dapat dilihat bahwa sarana prasarana pendukung kesiapsiagaan sekolah terhadap bencana gempa bumi di SMP Muhammadiyah 3 Cawas ditinjau dari parameter rencana tanggap darurat, guru yang mengetahui adanya gugus sekolah siaga bencana, seperti: kelompok peringatan bencana, evakuasi, pertolongan pertama, logistik, dan keamanan memiliki presentase $46 \%$ atau dapat dikatakan bahwa 6 dari 13 guru menjawab terdapatnya gugus sekolah siaga bencana di sekolah tersebut.

Terkait dengan mengetahui adanya prosedur tetap evakuasi termasuk prosedur tetap untuk gugus siaga bencana di sekolah, hanya 5 guru yang berpendapat demikian atau presentasenya sebesar $38 \%$. Kemudian 9 dari 13 guru sudah mengetahui tempat/titik evakuasi apabila terjadi gempa bumi, presentasenya sebesar 69\%. 1 dari 13 guru menjawab bahwa di sekolah tersebut terdapat peta evakuasi, nyatanya sekolah tersebut tidak mempunyai peta evakuasi apabila terjadi bencana gempa bumi, presentasenya sebanyak $8 \%$,

Pengetahuan guru terhadap adanya jalur evakuasi presentasenya sebesar 38\% atau 5 dari 13 guru sudah mengetahui adanya jalur evakuasi di sekolah tersebut, sedangkan pengetahuan guru dalam mengetahui adanya rambu evakuasi presentasenya sebesar 23\% atau 3 dari 13 guru sudah mengetahui adanya rambu evakuasi di sekolah tersebut. Ketersediaan panduan P3K menurut guru di sekolah tersebut yang menjawab "iya" hanya 4 dari 13 guru atau presentasenya sebanyak $31 \%$, kemudian menurut 9 dari 13 guru yang menjawab bahwa adanya tersedianya kotak/obat-obatan untuk pertolongan pertama saat terjadi bencana serta tersedianya posko/unit kesehatan sekolah atau presentasenya sebesar 
69\%. Menurut pendapat guru 5 dari 13 guru yang menjawab adanya petugas kesehatan yang terlatih di sekolah tersebut, memiliki presentase sebanyak $38 \%$.

Kesiapan sekolah dalam menyalin dokumen-dokumen penting yang disimpan di tempat aman memiliki presentase sebanyak $85 \%$ atau 11 dari 13 guru berpendapat demikian, hal ini merupakan antisipasi sekolah dalam menghadapi adanya suatu bencana agar dokumen tersebut tidak hilang. Tersedianya daftar alokasi kebutuhan dasar sekolah, seperti air minum, makanan awet/tahan lama, dan obat-obatan menurut guru pada sekolah tersebut memiliki presentase sebanyak 69\% atau 9 dari 13 guru berpendapat demikian, menurut pendapat 7 dari 13 guru yaitu adanya peralatan dan perlengkapan untuk keadaan darurat dengan presentase sebesar $54 \%$. Kemudian adanya tempat penyimpanan peralatan dan perlengkapan evakuasi yang aman menurut pendapat 4 dari 13 guru berpendapat demikian, dengan presentase sebesar $31 \%$.

8 dari 13 guru berpendapat bahwa adanya kesiapan guru dalam mencatat daftar alamat dan nomor telepon penting, seperti: nomor rumah sakit, pemadam kebakaran, polisi, PAM, PLN, Telkom serta terdapatnya surat/dokumen yang menyatakan kerjasama sekolah dengan instansi penting, memiliki presentase sebanyak $62 \%$. Tersedianya foto/dokumen yang menunjukkan adanya simulasi secara rutin dalam sekolah tersebut memiliki presentase sebanyak $8 \%$ atau 1 dari 13 guru berpendapat demikian, hal ini dikarenakan sekolah SMP Muhammadiyah 3 Cawas jarang melakukan aktivitas tentang simulasi kebencanaan baik dari pihak sekolah maupun pihak dari luar.

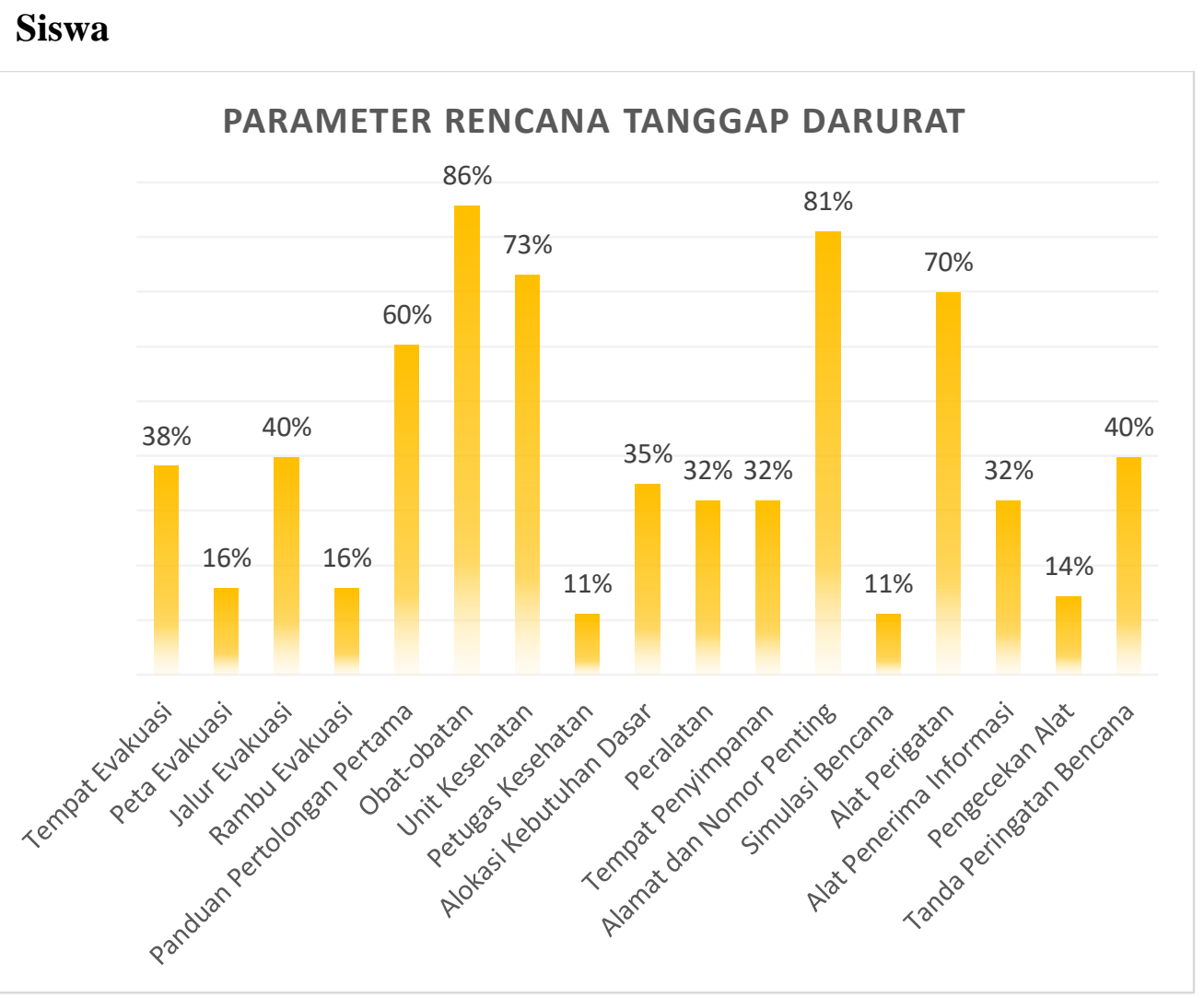

Gambar 6. Parameter Rencana Tanggap Darurat (Olah Data Peneliti, 2019)

Gambar 6 menunjukkan rencana tanggap darurat terhadap sarana prasarana pendukung bencana gempa bumi di SMP Muhammadiyah 3 Cawas. Dari data diatas dapat dilihat bahwa sarana prasarana pendukung kesiapsiagaan sekolah terhadap bencana gempa bumi di SMP Muhammadiyah 3 Cawas ditinjau dari parameter rencana tanggap darurat, menurut 24 dari 63 siswa berpendapat bahwa adanya tempat evakuasi di sekolah tersebut apabila ada bencana gempa bumi atau presentasenya sebanyak $38 \%$, tersedianya peta evakuasi bencan gempa bumi di sekolah memiliki presentase $16 \%$ atau dapat dikatakan hanya 10 dari 63 siswa yang berpendapat demikian, 25 dari 63 siswa berpendapat bahwa mengetahui 
adanya jalur evakuasi di sekolah tersebut atau presentasenya sebesar 40\%, serta 10 dari 63 berpendapat bahwa mengetahui adanya rambu evakuasi di sekolah tersebut atau presentaseya sebanyak $16 \%$.

Menurut 38 dari 63 siswa berpendapat bahwa adanya ketersediaan panduan P3K di sekolah tersebut atau memiliki presentase sebanyak $60 \%$, kemudian dilihat dari tersedianya kotak/obat-obatan untuk pertolongan pertama saat terjadi bencana memiliki presentase sebesar $86 \%$ atau dapat dikatakan bahwa 54 dari 63 siswa berpendapat demikian, dilihat dari tersedianya posko/unit kesehatan sekolah presentasenya sebesar $73 \%$ atau dapat dikatakan bahwa 46 dari 63 siswa berpendapat demikian, serta menurut pendapat siswa tentang adanya petugas kesehatan yang terlatih di sekolah tersebut yang menjawab "iya" hanya 7 dari 63 siswa atau presentasenya sebanyak $11 \%$.

Tersedianya daftar alokasi kebutuhan dasar sekolah, seperti air minum, makanan awet/tahan lama, dan obat-obatan menurut siswa pada sekolah tersebut memiliki presentase sebanyak $35 \%$ atau dapat dikatakan sebanyak 22 siswa menjawab bahwa terdapat daftar alokasi kebutuhan dasar, 20 dari 63 siswa berpendapat bahwa adanya peralatan dan perlengkapan untuk keadaan darurat serta tempat penyimpanan peralatan dan perlengkapan evakuasi yang aman menurut siswa dengan presentase sebesar $32 \%$. Kesiapan sekolah dalam mencatat daftar alamat dan nomor telepon penting, seperti: nomor rumah sakit, pemadam kebakaran, polisi, PAM, PLN, Telkom memiliki presentase sebanyak $81 \%$ atau dapat dikatakan 51 dari 63 siswa sudah mengetahui bahwa sekolah telah mencatat daftar alamat dan nomor telepon penting,

7 dari 63 siswa berpendapat bahwa adanya aktivitas simulasi kebencanaan di sekolah dengan presentase sebanyak $11 \%$. Ketersediaan alat yang dapat mengeluarkan bunyi (kentongan, lonceng, dan tiang bendera) sebagai tanda peringatan bencana gempa bumi menurut pendapat siswa disekolah tersebut memiliki presentase sebesar $70 \%$ atau dapat dikatakan bahwa 44 dari 63 siswa berpendapat bahwa tersedianya alat peringatan dini, kemudian menurut 20 dari 63 siswa berpendapat bahwa adanya alat penerima informasi peringatan bencana dari pemerintah (BMKG, Pemkot/pemda), dan media yang dapat dipertanggung jawabkan dengan presentase sebanyak $32 \%$.

Keterlibatan siswa dalam melakukan pengecekan secara berkala terhadap alat peringatan bencana, alat penerima resmi dan jaringan presentasenya sebanyak 14\% dapat dikatakan bahwa 9 dari 63 siswa berpendapat bahwa siswa terlibat dalam pengecekan alat peringatan bencana secara berkala, kemudian hanya 25 dari 63 siswa yang mengetahui bunyi khusus dari alat peringatan bencana atau tanda apabila terjadi bencana gempa bumi, suaranya jelas dan dipahami warga sekolah dan sekitarnya atau presentasenya sebanyak $40 \%$.

\section{Kesimpulan}

Berdasarkan penelitian yang dilakukan di SMP Muhammadiyah 3 Cawas, dapat disimpulkan bahwa sarana prasarana pendukung kesiapsiagaan sekolah terhadap bencana gempabumi masih kurang siap jika dilihat dari rerata parameter struktural sekolah. Pengetahuan mengenai bencana gempabumi masih dikatakan rendah, hal ini menunjukkan bahwa diperlukan adanya peningkatan sarana prasarana sebagai pendukung kesiapsiagaan terhadap bencana gempabumi di sekolah. Peningkatan ini diperlukan guna meminimalisir risiko yang timbul akibat bencana gempa bumi terutama sarana prasarana di sekolah tersebut, sehingga keamanan dan keselamatan komunitas sekolah terjaga. Diperlukan peningkatkan sarana prasana pendukung kesiapsiagaan bencana gempabumi di SMP M 3 Cawas. Upaya tersebut dilakukan guna menciptakan sekolah aman bencana. Kegiatan sosialisasi dan simulasi mitigasi bencana gempabumi yang dilakukan di SMP M 3 Cawas harus dilakukan secara berkala, agar kesiapsiagaan komunitas sekolah meningkat. Hal tersebut dapat mengurangi risiko yang mungkin terjadi saat bencana gempabumi.

\section{Ucapan Terimakasih}

Puji syukur kehadirat Tuhan Yang Maha Esa, atas limpahan rahmat-Nya sehingga penulis dapat menyelesaikan artikel dengan baik. Terimakasih kami ucapkan kepada seluruh pihak yang telah membantu penyelesaian artikel. Adanya artikel ini semoga dapat digunakan oleh masyarakat umum 
sebagai pengetahuan umum dan wawasan sebagai acuan dalam upaya pengembangan ekowisata berbasis masyarakat.

\section{Daftar Rujukan}

Avianto Amri. (2017). Pendidikan Tangguh Bencana. Jakarta : Sekertariat Nasional Satuan Pendidikan Aman Bencana Direktorat Pembinaan Pendidikan Khusus dan Layanan Khusus Direktorat Jendral Pendidikan Dasar dan Menengah Kementerian Pendidikan dan Kebudayaan (Kemendikbud).

Badan Nasional Penanggulangan Bencana (BNPB). (2010). Rencana Nasional Penanggulangan Bencana 2010 - 2014. Jakarta: Badan Nasional Penanggulangan Bencana (BNPB).

Budi Satria. "Sarana Dan Prasarana Pendukung Kesiapsiagaan Bencana Sekolah”. Idea Nursing Jurnal Vol.9. 2018.

BMKG. (2015). Badan Meteorologi, Klimatologi , dan Geofisika. Retrieved from http://inatews.bmkg.go.id/new/glossary.php

BNPB. (2018). Pedoman Penerapan Sekolah/Madrasah Aman Dari Bencana.

Carter, Nick. (1991). Disaster Management: A Disaster Manager Hand Book. ADB: Manilla

Cindrawaty,L.,\&Nurul,P.(2015). Kesiapsiagaan Komunitas Sekolah Dalam Menghadapi Bencana Di Kabupaten Magelang. Jurnal Teknik Sipil, 1-75.

Dedi Hermon. Mitigasi Bencana Hidrometeorologi. 2018. Universitas Negeri Padang Press.

Ella Yulaelawati, P., \& Usman Syihab, P. (2008). Mencerdasi Bencana: banjir, tanah longsor, tsunami, gempa bumi, gunung api, kebakaran. Jakarta: Grasindo.

INEE. 2011. Standar-Standar Minimum Untuk Pendidikan. Moc Publishing. Jakarta. 2011.

Kementerian Pendidikan dan Kebudayaan (Kemendikbud). (2004). Retrieved from https://www.kemdikbud.go.id/main/

Kementerian ESDM. (2009).Energi dan Sumberdaya Mineral. Retrieved from https://www.esdm.go.id

Mohd Robi Amri. 2016. Resiko Bencana Indonesia. BNPB. Jakarta. 2016.

Nasir, SKM. (2019). E- Learning Disaster Management. Retrieved from info@indonesiax.co.id

Nia Fauziah. (2010). "Sarana Dan Prasarana Pendukung Kesiapsiagaan Bencana Sekolah”. Skripsi. Jakarta. Fakultas Ilmu Tarbiyah Dan KeguruanUIN Syarif Hidayatullah Jakarta.

Nugroho, C. (2007). Kajian Kesiapsiagaan Masyarakat dalam Mengantisipasi Bencana Gempa Bumi dan Tsunami di Kabupaten Nias Selatan. Jakarta.

Peraturan Menteri Dalam Negeri No. 33 Tahun 2006. 
Rofika Sinaga . 2018. "Kajian Evaluasi Kinerja Bangunan Terhadap Siaga Bencana Gempa”. Jurnal Teknik Sipil Vol.41. 2018.

Rachmat, A. (2015). Partisipasi Masyarakat Dalam Mitigasi.

Sugiyino. (2015). Metode PenelitianPendidikan. Bandung: Alfabeta, CV.

Sugiyino. (2017). Metode Penelitian Kuantitatif, Kualitatif dan R\&D. Bandung: Alfabeta, CV.

Undang-Undang. (2007). Undang-Undang Republik Indonesia Nomor 24 Tahun 2007 Tentang Penanggulangan Bencana. Jakarta.

Undang-Undang. (2008). Undang-Undang Republik Indonesia Nomor 8 Tahun 2008 Tentang Badan Nasional Penanggulangan Bencana. Jakarta.

Yulianto, F. (2015). Management Bencana Di Indonesia. Siklus Disaster Management atau Disaster Management. 